\title{
p53 expression and K-ras mutation in colorectal adenomas
}

\author{
N Scott, S M Bell, P Sagar, G E Blair, M F Dixon, P Quirke
}

\begin{abstract}
The frequency of p53 overexpression and $\mathrm{K}$-ras codon 12 mutation was investigated in a series of colorectal adenomas. p53 was detected by immunohistochemistry in only $5 \%$ of tumours, whereas $\mathrm{K}$-ras mutation was found in eight of $\mathbf{3 0}$ adenomas examined. In vitro, mutant p53 and ras genes cooperate to transform primary rat cells into a tumourigenic cell line. The presence of both p53 overexpression and $\mathbf{K}$-ras mutation in a benign tubulovillous polyp in the present series suggests that in vivo this combination of events is insufficient to cause malignant transformation of a large bowel adenoma.
\end{abstract}

(Gut 1993; 34: 621-624)

A range of genetic alterations have recently been described in colorectal cancer and its benign precursor, the large bowel adenoma. Some of these changes seem to occur at an early stage of the neoplastic process. Hypomethylation of DNA, chromosome 5q deletion, and mutations in the newly identified MCC and APC genes have been identified in both adenomas and carcinomas suggesting that these are early events in the adenoma-carcinoma sequence. ${ }^{1-4}$ Conversely, deletions affecting the DCC locus on chromosome $18 \mathrm{q}$ and deletions in the region of the $\mathrm{p} 53$ gene on $17 p$ are found preferentially in carcinomas and therefore seem to be involved in the later stages of large bowel tumourigenesis. ${ }^{2} \mathrm{p} 53$ gene mutation or deletion seems to be an important and common event not only in colorectal carcinogenesis but also in many other human tumours. Raised levels of p53 have been described in 44\% of $67 \%$ of large bowel cancers, ${ }^{5-9} 36 \%$ of breast carcinomas, ${ }^{10}$ and $70 \%$ of lung tumours,,${ }^{11}$ as well as in malignant gliomas, bladder carcinoma, oesophageal carcinoma, ovarian carcinoma, and mesothelioma. In a previous study we described overexpression of the p 53 protein in $42 \%$ of 52 colorectal carcinomas, using the immunohistochemical detection of p53 as a marker of gene mutation. ${ }^{12}$ The validity of this approach has been borne out by other studies combining immunocytochemistry with DNA sequencing that have found accumulation of protein to be invariably associated with the presence of a mutant p53 allele. ${ }^{7113}$

p53 mutants are well known to be capable of cellular immortalisation, and act as nuclear oncogenes in a manner similar to c-myc. ${ }^{14}$ 15 This action of the mutant protein is in contrast with the recently established tumour suppressor activity of the wild type protein. ${ }^{16}$ As well as transformation of established $3 \mathrm{~T} 3$ cells, p53 will also cooperate with mutant ras genes to transform primary rat cells. ${ }^{1718}$ In at least one study transformed cells harbouring mutant p53 and ras genes were capable of growing in syngeneic laboratory animals, eventually leading to their death. ${ }^{17}$ Because point mutations in K-ras and p53 are common events in colorectal carcinoma, occurring in up to $40 \%$ and $67 \%$ of tumours respectively, it would be of interest to determine whether $\mathrm{p} 53$ and $\mathrm{K}$-ras also cooperate in vivo to produce invasive carcinoma.

The aim of this study therefore was to investigate the frequency with which p53 is overexpressed in large bowel adenomas; to define which, if any, of these adenomas also contain a mutant $\mathrm{K}$-ras gene; and to relate these findings to the presence of malignant change.

\section{Materials and methods}

\section{SAMPLES}

Fresh tissue was available from 38 sporadic adenomas (33 patients), together with two small tubular adenomas from a patient with familial adenomatous polyposis (FAP). Fifteen of the sporadic adenomas were less than $2 \mathrm{~cm}$ in size, 16 were greater than or equal to $2 \mathrm{~cm}$ in size, and seven had undergone focal malignant transformation, characterised by invasion of neoplastic epithelium through the muscularis mucosae. In the case of malignant polyps only adenomatous mucosa distant from the invasive tumour was selected for analysis. One of us (NS) classified and graded the adenomas according to criteria described by Konishi and Morson. ${ }^{19}$

\section{p53 IMMUNOHISTOCHEMISTRY}

Immunohistochemistry for p53 was performed with a standard technique previously described. ${ }^{12}$ Briefly, $4 \mu \mathrm{m}$ thick frozen sections were fixed in acetone at $4^{\circ} \mathrm{C}$ for 15 minutes, washed in TRIS buffered saline and incubated successively with primary anti-p53 antibody, biotinylated rabbit anti-mouse immunoglobulin, and streptavidin peroxidase. Antibody binding was visualised with amino-ethylcarbazole. All 40 adenomas were incubated with Pab 421 and 1801, monoclonal antibodies raised against different epitopes found on both wild type and mutant $\mathrm{p} 53$ protein. Sixteen specimens were also stained with Pab 240, a novel antibody that binds specifically to the mutant conformation. ${ }^{20}$ Each set of sections included a positive colorectal carcinoma control, and a negative control in which the primary antibody was omitted

K-RAS MUTATION ANALYSIS

Point mutations in the first two base pairs of $\mathrm{K}$-ras codon 12 were sought by a method pre-
Dr N Scott, Academic Unit of Pathology, Department of of Leeds, Leeds LS2 9JT.

Accepted for publication 15 September 1992 


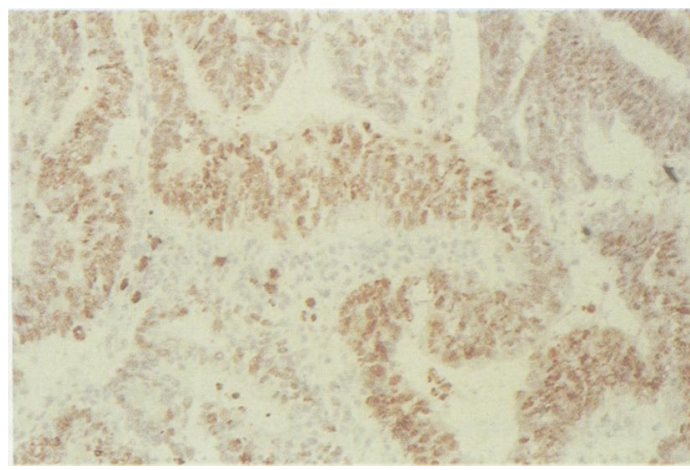

Figure 1: Adenoma showing heterogenous immunohistochemical staining for p53 (original magnification $\times 40)$.

viously described, ${ }^{21}$ and modified from the nonradioactive restriction enzyme technique of Jiang et al. ${ }^{22}$ Mutations in codons 13 and 61 , which occur much less often in large bowel tumours, were not analysed in this preliminary study. Thirty adenomas were examined. DNA for polymerase chain reaction (PCR) was extracted from sections of fresh tissue immediately adjacent to those used for immunohistochemistry. Three to five $10 \mu \mathrm{m}$ sections were incubated with $2 \mathrm{mg} / \mathrm{ml}$ proteinase $\mathrm{K}$ and $1 \%$ sodium dodecyl sulphate for 3 days at $37^{\circ} \mathrm{C}$. The sample was then extracted twice with an equal volume of phenol:chloroform:isoamyl alcohol (24:1). After ethanol precipitation of the aqueous phase at $-20^{\circ} \mathrm{C}$ DNA was recovered by centrifugation, dried, and resuspended in distilled water.

With primers described by Jiang et $a l$ and synthesised on an Applied Biosystems DNA synthesiser a $157 \mathrm{bp}$ fragment of the K-ras gene was amplified containing codon 12 . Details of the

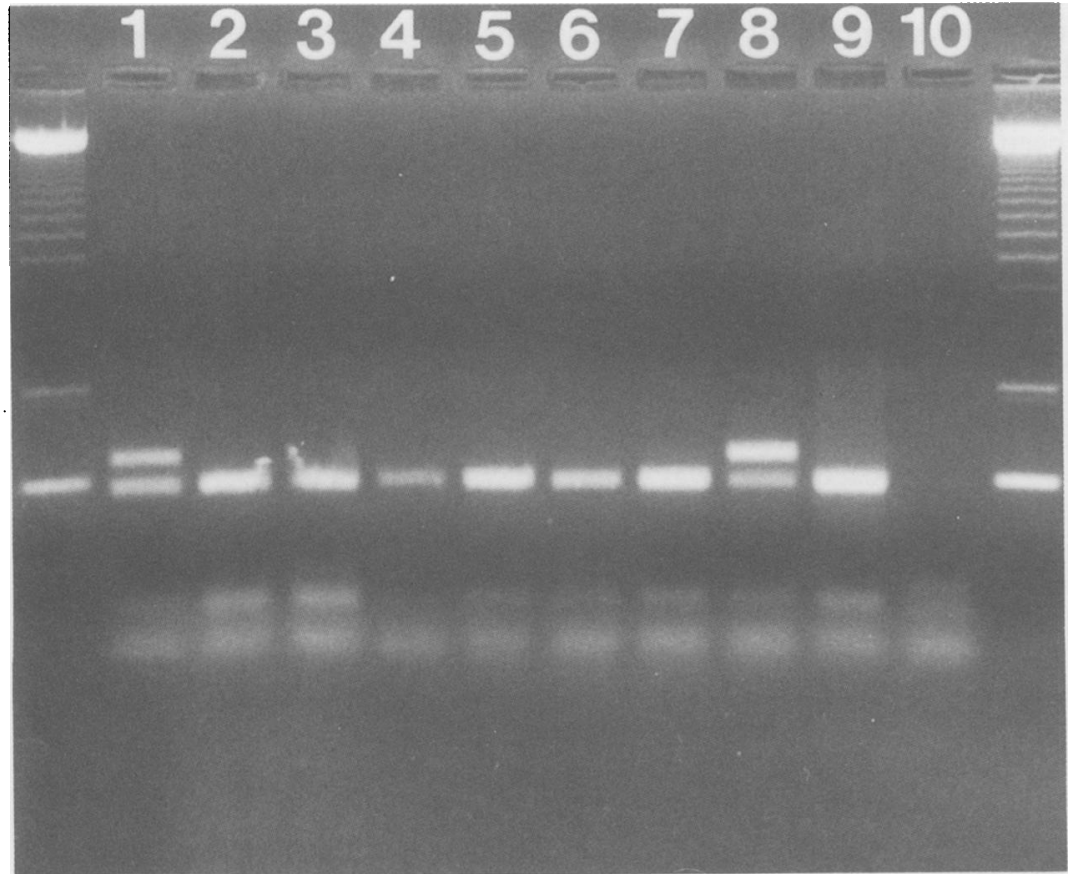

Figure 2: Agarose gel stained with ethidium bromide to show band pattern of mutant and wild type K-ras alleles after Bst N1 digestion. Lanes 1 and 8 contain codon 12 mutants in which a potential restriction site has been lost. Lanes $2-7$ and 9 contain wild type K-ras only. Lane 10 is a negative control containing water instead of DNA.
K-ras codon 12 mutations in 30 large bowel adenomas

\begin{tabular}{lrl}
\hline Adenoma & $N o$ & $K$-ras mutation $(\%)$ \\
\hline Size: & & \\
$\quad<2 \mathrm{~cm}$ & 14 & $2(14)$ \\
$\quad \geqslant 2 \mathrm{~cm}$ & 12 & $4(33)$ \\
Malignant* & 4 & $2(50)$ \\
Mild dysplasia & 10 & $0(0)$ \\
Moderate dysplasia & 12 & $4(33)$ \\
Severe dysplasia & 8 & $4(50)$ \\
Total & 30 & $8(27)$ \\
\hline
\end{tabular}

^Adenomas showing focal malignant change.

polymerase chain reaction are given in a previous publication. $^{21}$ A negative control containing water instead of DNA was included in each reaction. The amplified sequence was visualised on a $2 \%$ ethidium bromide stained GTG agarose gel (FMC Bioproducts, Rockland ME, USA) before proceeding to restriction enzyme digestion.

Sixteen microlitres of the amplified PCR product was digested with BstN1 in a total volume of $25 \mu \mathrm{l}$ under conditions recommended by the suppliers (Boehringer, Mannheim UK, Lewes, Sussex). The digestions were incubated at $60^{\circ} \mathrm{C}$ overnight and the products analysed on a $3 \%$ ethidium bromide stained $\mathrm{Nu}$ sieve agarose gel (FMC Bioproducts). Each digestion included a positive colorectal carcinoma or adenoma control known to contain a mutation at codon 12 .

\section{Results}

Only two out of 38 sporadic adenomas were found to overexpress p 53 protein. One of these was a $2 \mathrm{~cm}$ diameter tubulovillous adenoma exhibiting severe dysplasia, and the other was an $8 \mathrm{~cm}$ diameter villous adenoma that had undergone focal malignant change. Unfortunately fresh tissue was not available from the carcinoma, and therefore it was impossible to say whether it also contained a p53 gene mutation. Staining in the two polyps was nuclear and positive with all three p53 antibodies, confirming the presence of a mutant protein phenotype. The distribution of staining was more heterogenous than that previously described in carcinomas with several areas of the polyp failing to express detectable levels of p53 protein. Figure 1 shows the strong nuclear staining seen in one of these adenomas. Neither of the two $0.5 \mathrm{~cm}$ diameter FAP adenomas overexpressed p53.

$\mathrm{K}$-ras codon 12 mutations were found in a total of eight out of 30 sporadic adenomas examined. Figure 2 shows a typical BstN1 digest containing examples of both mutant and wild type K-ras alleles. Mutations were notably more frequent in larger adenomas, in adenomas that had undergone focal malignant transformation, and in adenomas exhibiting severe dysplasia (Table). Of particular interest was the coexistence of a mutant $\mathrm{K}$-ras allele and p53 overexpression in the $2 \mathrm{~cm}$ tubulovillous polyp described earlier. By contrast the single malignant polyp identified as expressing a mutant type $\mathrm{p} 53$ protein did not seem to contain a mutation at codon 12 of the K-ras gene, although obviously we cannot currently exclude the presence of codon 13 or 61 mutations. 


\section{Discussion}

Overexpression and mutation of the p53 gene is now well described in large bowel cancer. There are few reports, however, of $\mathrm{p} 53$ gene alterations in the precursor adenoma. Van den Berg $e t a l^{6}$ studied 74 adenomas, including 12 FAP polyps, and found that $10 \%$ of the sporadic and $17 \%$ of the FAP adenomas overexpressed p53. No clear relation was found with degree of dysplasia, and no information was given pertaining to size or presence of malignant change. Napier $e t a l^{23}$ described p53 staining in one of $11(9 \%)$ adenomas, Rodrigues et $\mathrm{al}^{7}$ in none out of 10 , and Campo et $a l^{8}$ found increased expression in two out of 18 adenomas (11\%). More recently Shaw et $a l^{9}$ have sequenced exons 5, 6, and 7 of the p53 gene in 19 polyps without finding any mutations whereas Baker et al reported point mutations in $10 \%$ of 19 adenomas retaining both p 53 alleles. ${ }^{24}$ Our finding in this study that only $5 \%$ of sporadic adenomas express detectable levels of p53 protein is clearly in line with the results of these other workers, and the use of three different anti-p53 antibodies including 'mutant specific' Pab 240, provides further evidence that the protein detected is a mutant form.

The use of immunohistochemical staining as a marker of point mutation has been critically reviewed by Wynford-Thomas. ${ }^{25}$ Although inconsistencies clearly exist, most studies of large bowel tumours show a very strong correlation between immunocytochemical positivity and p 53 mutation. Rodrigues et al found six of six colorectal cancer cell lines overexpressing p53 to contain a point mutation, and Purdie et al described complete agreement between staining with Pab 240 and presence of a mutation in 12 primary large bowel cancers. ${ }^{72}$

It is of interest that the positive tumours in the present series were both 'large' polyps $\geqslant 2 \mathrm{~cm}$ in size, and that one had undergone focal malignant transformation. The rarity of $\mathrm{p} 53$ gene mutation in adenomas and its prevalence in carcinomas, suggests that p53 mutation is one of the late events in the adenoma-carcinoma sequence, occurring either at the adenoma carcinoma interface or during progression of established cancers. This distribution of $\mathrm{p} 53$ gene mutation between adenomas and carcinomas mirrors that of chromosome $17 \mathrm{p}$ deletion, believed to signal loss of a wild type p 53 allele. ${ }^{2}$ Inactivation of one p53 allele by mutation, and the other by deletion, may be important for colorectal carcinogenesis in the same way that deletion of the $R b$ gene is necessary for the development of retinoblastoma. This interpretation is supported by the demonstration of tumour suppressor activity of wild type p53 in at least two in vitro systems, ${ }^{1627}$ and the finding that reintroduction of the wild type p53 gene into a colorectal carcinoma cell line with one p53 gene mutated and the other deleted, results in suppression of growth. ${ }^{28}$

K-ras gene mutations, by contrast with $\mathrm{p} 53$, clearly occur at an earlier stage in the neoplastic sequence. Vogelstein $e t a l^{2}$ have described ras mutations in $12 \%$ of sporadic adenomas $<1 \mathrm{~cm}$ in size, $20 \%$ of tumours 1 to $2 \mathrm{~cm}$ in size, $100 \%$ of adenomas $>2 \mathrm{~cm}$, and in $60 \%$ of adenomas that contain a carcinoma. Other workers have found ras gene mutations in between $39 \%$ and $47 \%$ of colorectal cancers. ${ }^{2930}$ Our results closely resemble those of Vogelstein et al with a higher prevalence of mutant $\mathrm{K}$-ras genes in larger adenomas, adenomas harbouring cancer, and adenomas exhibiting severe dysplasia.

A particularly interesting finding was that of a benign tubulovillous polyp that contained both a mutant $\mathrm{K}$-ras and a $\mathrm{p} 53$ allele. In vitro ras and p53 mutants cooperate to transform primary rat cells into cells capable of lethal tumourigenesis. This does not seem to be the case in vivo, at least not in the colorectum. Our findings suggest that this combination is insufficient on its own to cause an adenoma to become malignant. Supporting evidence for the non-cooperation of p53 and $\mathrm{K}$-ras in colorectal tumourigenesis comes from our own finding and that of others that the frequency with which p 53 and $\mathrm{K}$-ras mutants are found together in large bowel cancers is only that to be expected by chance. ${ }^{31}{ }^{32}$ If this combination of mutations were of biological significance preferential selection of cells with the double mutant phenotype might be expected, leading to clonal expansion of the mutant population. Another piece of evidence that $\mathrm{p} 53$ and K-ras do not cooperate in large bowel epithelium is the finding of ras mutation accompanied by $\mathrm{p} 53$ overexpression in an adenoma cell line, isolated by Dr C Paraskevas (personal communication). It may be that deletion of the remaining wild type p53 allele is also required before mutant p53 and $\mathrm{K}$-ras exert their cooperative effect.

In conclusion, we have shown that $\mathrm{p} 53$ mutation, as indicated by overexpression of the protein and immunoreactivity with Pab 240, is an uncommon event in adenomas compared with colorectal carcinomas. K-ras codon 12 mutation, however, is much more common and seems to be related to size and degree of dysplasia. Unlike the situation in vitro, in vivo the combination of $\mathrm{K}$-ras and $\mathrm{p} 53$ mutation seems to be insufficient to cause malignant change in a large bowel tumour. The critical event which determines malignancy in the adenoma-carcinoma sequence therefore remains unclear. Further definition of the in vivo interaction between p53 mutation, p53 deletion and $\mathrm{K}$-ras mutation is urgently required.

This work was supported by a grant from the Yorkshire Cancer Research Campaign. We would like to thank Miss J Hamblin for typing the manuscript and $\mathrm{Mr} \mathrm{S}$ Toms for photographic assistance. We are also grateful to Dr D Lane for making available the monoclonal antibody Pab 240.

1 Goelz SE, Vogelstein B, Hamilton SR, Feinberg AP. Hypomethylation of DNA from benign and malignant human colon neoplasms. Science 1985; 228: 187-90

2 Vogelstein B, Fearon ER, Hamilton SR, Kern SE, Presinger AC, Leppert M, et al. Genetic alterations during colorecta tumor development. $N$ Engl F Med 1988; 319: 525-32.

3 Kinzler KW, Nilbert MC, Vogelstein B, Bryan TM, Levy $\mathrm{DB}$, Smith KJ, et al. Identification of a gene located at chromosome 5q21 that is mutated in colorectal cancers. Science 1991; 251: 1366-9.

4 Joslyn G, Carlson M, Thliveris A, Albertsen H, Gelbert L, Samowitz W, et al. Identification of deletion mutations and three new genes at the familial polyposis locus. Cell 1991; 66:

5 CrawfordLV, Pim DC, Lamb P. The cellular protein p53 in human tumours. Mol Biol Med 1984; 2: 261-72.

6 Van den Berg FM, Tigges AJ, Schipper MEI, Den HartogJager FCA, Kroes WGM, Walboomers JMM. Expression of the nuclear oncogene $\mathrm{p} 53$ in colonic tumours. F Pathol 1989; 157: 193-9.

7 Rodrigues NR, Rowan A, Smith MEF, Kerr IB, Bodmer WF, Gannon JV, et al. $\mathrm{p} 53$ mutations in colorectal cancer. Proc Natl Acad Sci 1990; 87: 7555-9. 
8 Campo E, de la Calle-Martin O, Miquel R, Palacin A, Romero $M$, Fabregat $V$, et al. Loss of heterozygosity of $\mathrm{p} 53$ gene and 53 protein expression in human colorectal carcinomas. p53 protein expression in hum

9 Shaw P, Tardy S, Benito E, Obrador A, Costa J. Occurrence of $\mathrm{Ki}$-ras and $\mathrm{p} 53$ mutations in primary colorectal tumors. Oncogene 1991; 6: 2121-8.

10 Ostrowski JL, Sawan A, Henry L, Wright C, Henry JA, Hennessy C, et al. p53 expression in human breast cance related to survival and prognostic factors: an immunohistochemical study. $\mathcal{F}$ Pathol 1991; 164: 75-81.

11 Iggo R, Gatter K, Bartek J, Lane D, Harris AL. Increased expression of mutant forms of $\mathrm{p} 53$ oncogene in primary lung cancer. Lancet 1990; 335: 675-9.

12 Scott N, Sagar P, Stewart J, Blair GE, Dixon MF, Quirke P. p53 in colorectal cancer: clinicopathologic correlation and p53 in colorectal cancer: clinicopathologic correlation

13 Bartek J, Iggo R, Gannon J, Lane DP. Genetic and immunochemical analysis of mutant $\mathrm{p} 53$ in human breast cancer cell chemical analysis of mutant p53 in

14 Jenkins JR, Rudge K, Currie GA. Cellular immortalization by a cDNA clone encoding the transformation associated phosphoprotein p53. Nature $1984 ; 312: 651-3$.

15 Rovinski B, Benchimol S. Immortalization of rat embry fibroblasts by the cellular p 53 oncogene. Oncogene 1988; 2 . 445-52.

16 Finlay CA, Hinds PW, Levine AJ. The p53 proto-oncogene can act as a suppressor of transformation. Cell 1989; 57 : 1083-93.

17 Eliyahu D, Raz A, Gruss P, Givol D, Oren M. Participation of p53 cellular tumour antigen in transformation of normal embryonic cells. Nature 1984; 312: 646-9.

18 Parada LF, Land H, Weinberg RA, Wolf D, Rotter V. Cooperation between gene encoding p53 tumour antigen and ras in cellular transformation. Nature 1984; 312: 649-51.

19 Konishi F, Morson BC. Pathology of colorectal adenomas: a colonoscopic survey. F Clin Pathol 1982; 35: 830-41.

20 Gannon JV, Greaves R, Iggo R, Lane DP. Activating mutations in 53 produce a common conformational effect.
A monoclonal antibody specific for the mutant form. A monoclonal antibody spec

21 Bell SM, Kelly SA, Hoyle JA. c-ki-ras gene mutations in dysplasia and carcinomas complicating ulcerative colitis. dysplasia and carcinomas con

22 Jiang W, Kahn SM, Guillem JG, Lu SH, Weinstein B. Rapid detection of ras oncogenes in human tumors: applications to colon, esophageal and gastric cancer. Oncogene 1989; 4 923-8.

23 Napier JM, Purdie CA, Wyllie AH. Intranuclear p53 in human colorectal tumours. $\mathcal{F}$ Pathol 1989 ; 158: 234 a

24 Baker SJ, Presinger AC, Milburn Jessup J, et al. p53 gene mutations occur in combination with $17 \mathrm{p}$ allelic deletions as late events in colorectal tumorigenesis. Cancer Res 1990;50: 7717-22.

25 Wynford-Thomas D. p53 in tumour pathology: can we trust immunocytochemistry? $\mathcal{P}$ Pathol 1992; 166: 329-30.

26 Purdie CA, Jenkins JR, Wyllie AH, Bird CC. p53 mutations and chromosome $17 \mathrm{p}$ deletions in colorectal cancer. $\mathcal{F}$ Pathol and chromosome 1 1991: $156 \mathrm{~A}$.

27 Chen P, Chen Y, Bookstein R, Lee W-H. Genetic mechanisms of tumor suppression by the human p53 gene. Science 1990 250: 1576-9.

28 Baker SJ, Markowitz S, Fearon ER, Willson JKV, Vogelstein B. Suppression of human colorectal carcinoma cell growth by wild-type p53. Science 1990; 249: 912-5.

29 Bos JL, Fearon ER, Hamilton SR, de-Vries M, van Boom J, vander $\mathrm{Eb} \mathrm{A}$, et al. Prevalence of ras gene mutations in human colorectal cancers. Nature 1987; 327: 293-7.

30 Forrester K, Almoguera C, Han K, Grizzle WE, Perucho M. Detection of high incidence of $\mathrm{K}$-ras oncogenes during Detection of high incidence of K-ras oncogenes during
human colon tumorigenesis. Nature $1987 ; 327: 298-303$.

31 Bell SM, Scott N, Cross D, Sagar P, Lewis FA, Blair GE, et al. Prognostic value of p53 and c-ki-ras gene mutations in colorectal cancer. Gastroenterology (in press).

32 Wyllie AH, Lang S, Purdie CA, Evans I, Bird CC. p53 and ki-ras oncogenes do not cooperate in human colorecta carcinogenesis. F Pathol 1991; 163: 169A 